\title{
Assessment of Potential Toxic Elements in Muscle Tissues of Different Fish Species from Colentina, Dambovita and Arges Rivers, Romania
}

\author{
PETRA IONESCU ${ }^{1,2}$, VIOLETA-MONICA RADU ${ }^{1,2 *}$, GYORGY DEAK ${ }^{1}$, \\ ELENA DIACU ${ }^{2 *}$, ALEXANDRU ANTON IVANOV ${ }^{1}$, IRINA-ELENA CIOBOTARU ${ }^{1}$, \\ ECATERINA MARCU ${ }^{1}$ \\ ${ }^{1}$ National Institute for Research \& Development in Environmental Protection, 294 Splaiul Independentei, 060031, Bucharest, \\ Romania \\ ${ }^{2}$ University Politehnica of Bucharest, Faculty of Applied Chemistry and Materials Science, 1-7 Polizu Str., 011061, \\ Bucharest, Romania
}

\begin{abstract}
At global level, anthropic activities have led to the emergence in the environment of different toxic substances, which tend to accumulate within the food chain, thus presenting risks to human health. As a result, the assessment of potentially toxic elements, particularly heavy metals, in fish is highly important from the point of view of human health as fish is frequently consumed by people. This paper presents the results of a study on determining some potential toxic elements such as $\mathrm{Cd}, \mathrm{Pb}, \mathrm{Hg}, \mathrm{Cu}, \mathrm{Cr}$, $\mathrm{Ni}$ and $\mathrm{Zn}$ in muscle tissue resulting from six different fish species (Alburnus alburnus, Carassius gibelio, Scardinius erythrophthalmus, Ameiurus nebulosus, Perca fluviatilis, Lepomis gibbosus) from the Colentina, Dambovita and Arges Rivers situated in southern Romania area, and to compare the results with the relevant international guidelines.
\end{abstract}

Keywords: potentially toxic elements, heavy metals, fish, bioaccumulation factor

\section{Introduction}

Contamination of the environment with toxic substances, especially heavy metals, has raised concerns due to their persistence in the environment, contamination of food chains and different health risks to humans [1-6]. The provisions of Water Framework Directive [7] and its Daughter Directives [8-11] are employed within the European Union for the prevention and control of surface water pollution, obliging the member states, including Romania, to monitor the quality of water, sediments and biota. Among the indicators to be monitored, the following potentially toxic elements ( $\left.\mathrm{PTE}_{\mathrm{s}}\right)$ are included: cadmium $(\mathrm{Cd})$, lead $(\mathrm{Pb})$, mercury $(\mathrm{Hg})$, arsenic $(\mathrm{As})$, copper $(\mathrm{Cu})$, chromium $(\mathrm{Cr})$, nickel $(\mathrm{Ni})$ and zinc $(\mathrm{Zn})$. Among PTEs, $\mathrm{Cd}, \mathrm{Pb}, \mathrm{Hg}, \mathrm{As}$, and $\mathrm{Cu}$ present a higher potential to be accumulated in aquatic species to concentrations exceeding recommended standard limits [12].

After entering into aquatic environment, the PTEs accumulate in tissues and organs of aquatic organisms [13]. It is important to determine concentrations of PTEs in fish tissues, because fish is known as a good bio-indicator for the contamination with potentially toxic elements as they occupy the different trophic levels and have different size and age, being constantly exposed to the chemical substances from contaminated water $[14,15]$. Regarding their presence in biological systems, heavy metals are classified as essential for living organisms ( $\mathrm{Mn}, \mathrm{Fe}, \mathrm{Cu}$, and $\mathrm{Zn})$ and nonessential $(\mathrm{Cd}, \mathrm{Pb}$, and $\mathrm{Hg})[6,16]$. Some features of these elements are presented below.

Cadmium and lead are not essential elements for humans, animals and plants [17]. The effects of cadmium on aquatic organisms are similar to the effects of the presence of this element on human health

*email: radumonica33@yahoo.com,elena_diacu@yahoo.co.uk 
and include skeletal deformations, effects of kidney functions, respiratory and reproductive disorders $[18,19]$. Lead in the water can cause generative damage in some aquatic life and cause blood and nervous changes in animals and fish [20,21]. The toxicity of lead is depends significantly on water quality, as its solubility decreases with the increase of $p \mathrm{H}$ and calcium and magnesium concentrations in water [22].

Inorganic mercury species, and organo-mercuric compounds may cause the serious damaging of fish tissues and vital organs and may exhibit harmful effects on reproduction. Bioconcentration and biomagnification of all mercury species depend on the age, size and fish species exposed to mercury, these effects increasing with the decreasing of the calcium concentration and water $p \mathrm{H}[23,24]$.

Copper is an essential micronutrient but at high concentrations it becomes one of the most toxic elements [25]. Copper toxicity to aquatic organisms depends on water alkalinity and hardness, as the hydroxyl and carbonate ions complex strongly with the copper ions thus decreasing its toxicity, while the increase of $p \mathrm{H}$ leads to an increase of copper toxicity [26].

Chromium and cadmium have synergistic action that is their combined toxicity exceeds the sum of their individual toxicities [24]. The toxicity of chromium depends on the species in which is present in water, thus trivalent chromium in ultra-trace concentrations is an essential element for living organisms, in high concentrations becoming toxic, while hexavalent chromium is extremely toxic. The physicochemical properties of water influence the toxicity of chromium on fish species, so that high $\mathrm{pH}$ and calcium content water lowers toxicity and high temperature water induces high toxicity [22, 24].

Aquatic organisms are affected also by nickel presence in water based on the interface with other factors, particular to each aquatic species, with references that oxidative stress can bring an important contribution to the nickel toxicity on freshwater fish species [27, 28]. The toxic effects of nickel on aquatic biota are due to three main mechanisms: inhibition of respiration, impaired ion regulation and stimulation of oxidative stress [29].

Another PTE present in water is zinc, in small concentrations being an indispensable element for growth. Its bioavailability in the aquatic environment depends on several biological and physicochemical parameters such as age and size of aquatic organism, exposure, water hardness, $p \mathrm{H}$, dissolved oxygen and temperature $[30,31]$. Increase of water temperature and the decrease of dissolved oxygen may favour the increase of zinc toxicity, whereas high calcium content may reduce its toxic effects [32].

In the present study, the area of interest is the southern part of Romania. The Dambovita River and its tributary, the Colentina River, cross the Bucharest city, which exerts a significant impact on these rivers quality, the Dambovita and Arges provide important sources of drinking water, irrigation water and fish intended for consumption. In the previous research, the extent of the contamination with potential toxic elements (heavy metals) of water and sediments from the Arges, Dambovita and Colentina Rivers (Mogosoaia, Herastrau and Pantelimon Lakes) has been evaluated. Concentrations of PTEs for analysed of water and sediment samples highlighted water and sediment quality, with emphasis of certain exceedances of legal limits and on the influence of pollution sources [33, 34]. In this context, there is a need to control the degree of bioaccumulation of PTEs in different species of fish destined for human consumption from the mentioned rivers, which has been the main objective of the present paper.

\section{Materials and methods} Study area

The study area, Colentina, Dambovita and Arges Rivers, was presented from the geographical point of view in previous studies [33, 34]. Figure 1 shows the study area and the Table 1presents details about the sampling campaigns conducted in June 2018 for Dambovita and Arges Rivers and in July 2016 for Colentina River (Mogosoaia, Herastrau and Pantelimon Lakes). This study was undertaken to investigate heavy metal concentrations in edible parts (muscle tissue) of six fish species because the concentration of heavy metals in fish available in this region was rarely or not at all investigated. 
Figure 1. The positioning of the sampling locations in Romanian study area:P1 - Dambovita River, P2 - Arges

River, P3 - Mogosoaia Lake, P4 Herastrau Lake and P5 - Pantelimon Lake. Upper insert - Romania map

Table 1

Sampling site locations

\section{Sampling, preparation and analysis}

The six investigated species are part of the families of Cyprinidae, Percidae, Ictaluridae and Centrarchidae. The species from the Cyprinidae family such as Alburnus alburnus, Carassius gibelio, Scardinius erythrophthalmus feeds mostly with plants, algae but also with small invertebrates. The species belonging to the Percidae family such as Perca fluviatilis are predators with high economic importance and feed especially with fish, worms and arthropods. Ameiurus nebulosus is part of the Ictaluridae family and it is an invasive species with no economic importance that feeds with aquatic invertebrates (hirudins, oligochaetes, insect larvae and crustaceans). Lepomis gibbosus is part of the Centrarchidae family and is considered to be an invasive species that may cause damage to indigenous species [35].

Fish samples were purchased from local fishermen and kept at $4^{\circ} \mathrm{C}$ during the transportation to the laboratory, where they were washed with bidistilled water. Species identification followed by quantification of length and weight was performed, the data regarding the sampling campaigns as well as data on analysed species and their characteristics are shown in Table 2.

Table 2

Data on biota sampling and its characteristics

\begin{tabular}{|c|c|c|c|c|c|}
\hline $\begin{array}{c}\text { Sampling } \\
\text { site }\end{array}$ & Species & $\begin{array}{c}\text { FAO } \\
\text { Names }\end{array}$ & $\begin{array}{c}\text { Number of fish } \\
\text { samples }\end{array}$ & $\begin{array}{c}\text { TL } \\
(\mathrm{cm})\end{array}$ & $\begin{array}{l}\text { BW } \\
(\mathrm{Kg})\end{array}$ \\
\hline $\mathrm{P} 1$ & $\begin{array}{l}\text { Perca fluviatilis } \\
\text { (Linnaeus, 1758) }\end{array}$ & European perch* & 4 & $13-15$ & $0.040-0.045$ \\
\hline \multirow{2}{*}{$\mathrm{P} 2$} & $\begin{array}{c}\text { Alburnus alburnus } \\
\text { (Linnaeus, 1758) }\end{array}$ & Bleak* & 16 & $8-11$ & $0.007-0.010$ \\
\hline & $\begin{array}{l}\text { Carassius gibelio } \\
\text { (Bloch, 1982) }\end{array}$ & Crucian carp* & 3 & $18-20$ & $0.100-0.110$ \\
\hline \multirow{4}{*}{ P3 } & $\begin{array}{l}\text { Alburnus alburnus } \\
\text { (bleak) }\end{array}$ & Bleak* & 7 & $10-13$ & $0.008-0.014$ \\
\hline & $\begin{array}{c}\text { Ameiurus nebulosus } \\
\text { (Lesueur, 1819) }\end{array}$ & Brown bullhead $* *$ & 2 & $11-12$ & $0.035-0.037$ \\
\hline & $\begin{array}{l}\text { Lepomis gibbosus } \\
\text { (Linnaeus, 1758) }\end{array}$ & Pumpkinseed $* *$ & 2 & $8-10$ & $0.020-0.022$ \\
\hline & $\begin{array}{c}\text { Scardinius } \\
\text { erythrophthalmus } \\
\text { (Linnaeus, 1758) }\end{array}$ & Rudd* & 5 & $9-11$ & $0.009-0.015$ \\
\hline P4 & $\begin{array}{c}\text { Scardinius } \\
\text { erythrophthalmus }\end{array}$ & Rudd* & 3 & $17-18$ & $0.076-0.085$ \\
\hline
\end{tabular}




\begin{tabular}{|c|c|c|c|c|c|}
\hline \multirow{3}{*}{ P5 } & Alburnus alburnus & Bleak* & 2 & $15.5-16$ & $0.036-0.037$ \\
\cline { 2 - 6 } & Carassius gibelio & Crucian carp* & 3 & $16-17$ & $0.078-0.079$ \\
\cline { 2 - 6 } & Perca fluviatilis & European perch* & 3 & $15.5-16$ & $0.050-0.051$ \\
\hline \multicolumn{6}{|c|}{ TL = total length, BW = body weight, *native species, **introduced species } \\
\hline
\end{tabular}

All reagents were of analytical grade purchased from Merck, Germany. Fish samples were gutted using a ceramic knife, skinless fillets and bone from the dorsal musculature were taken for analysis. Fish muscle tissue was dried at about $60{ }^{\circ} \mathrm{C}$ in the laboratory oven, milled to homogeneity in a non-metallic mortar. Berghoff microwave digestion system (MWS-4) equipped with a temperature and pressure soft was used to digest the fish samples. About $0.5 \mathrm{~g}$ of sample were weighed at analytical balance and digested using a mixture of $7 \mathrm{~mL}$ of $65 \%$ nitric acid and $3 \mathrm{~mL}$ of $30 \%$ hydrogen peroxide. Samples were analysed by atomic absorption spectrometry method using a High-Resolution Continuum Source Atomic Absorption Spectrometer - HRCSAAS ContrAA 700 (Analytik Jena) to determine the following PTEs: $\mathrm{Cd}, \mathrm{Pb}, \mathrm{Hg}, \mathrm{Cu}, \mathrm{Cr}, \mathrm{Ni}$ and $\mathrm{Zn}$. The quality of the obtained results was assured by analysing a certified reference material (European Reference Material - BB422, fish muscle certified reference material for trace metals) and this indicated a satisfactory performance of heavy metal detection within the range of certified values $(90 \%-110 \%)$.

\section{Results and discussions}

\section{Heavy metals concentration in the muscles of the different fish species}

In the context of establishing for the first time the maximum limits allowed for cadmium and lead in some food products and for mercury in fish products through the document Commission Regulation (EC) No. 466/2001 and the replaced by the Commission Regulation (EC) No. 1881/2006 and Commission Regulation (EC) No. 629/2008 [36-38], the monitoring the contaminants became essential in the view of the protection of public health. Table 3 shows those maximum acceptable levels in fish muscle tissue of the seven metals analysed in the present study as set by several international organizations.

Table 3

Maximum permissible level of heavy metals in fish according to international standards

\begin{tabular}{|c|c|c|c|c|c|c|c|c|c|}
\hline \multirow{2}{*}{\multicolumn{2}{|c|}{ Organization }} & $\mathrm{Cd}$ & $\mathrm{Pb}$ & $\mathrm{Hg}$ & $\mathrm{Cu}$ & $\mathrm{Cr}$ & $\mathrm{Ni}$ & $\mathrm{Zn}$ & \multirow{2}{*}{ References } \\
\hline & & \multicolumn{7}{|c|}{$\mathrm{mg} / \mathrm{Kg}$} & \\
\hline & EC, 2008 & 0.05 & 0.30 & 0.50 & - & - & - & - & {$[38]$} \\
\hline & EC, 2005 & 0.05 & 0.20 & 0.50 & - & - & - & - & [39] \\
\hline \multicolumn{2}{|c|}{$\begin{array}{l}\text { Australia New Zealand Food } \\
\text { Standards Code }\end{array}$} & - & 0.50 & 0.50 & - & - & - & - & [40] \\
\hline \multicolumn{2}{|c|}{ FAO/WHO, 2018} & - & 0.30 & - & - & - & - & - & [41] \\
\hline \multicolumn{2}{|r|}{ WHO 1989} & 1.00 & 2.00 & - & 30 & 50 & $\begin{array}{c}0.50- \\
1.00\end{array}$ & 100 & [42] \\
\hline \multirow{11}{*}{ 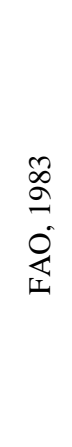 } & New South Wales & 5.50 & 5.50 & 0.50 & 30 & - & - & 40 & \multirow{11}{*}[43]{} \\
\hline & Western Australia & 5.50 & 2.50 & 1.00 & 10 & - & - & 150 & \\
\hline & South Australia & 0.20 & 5.50 & 1.00 & 30 & - & - & 40 & \\
\hline & Tasmania & 0.20 & 5.00 & 1.00 & 10 & - & - & 150 & \\
\hline & Victoria & 0.20 & 5.50 & & 30 & - & - & 1000 & \\
\hline & Brazilia & - & & 0.50 & & - & - & - & \\
\hline & Canada & - & 0.50 & 0.50 & & - & - & - & \\
\hline & Finalnd & - & & 1.00 & & - & - & - & \\
\hline & France & - & & 0.50 & & - & - & - & \\
\hline & $\begin{array}{l}\text { Germany, Federal } \\
\text { Republic of }\end{array}$ & 0.50 & 0.50 & 1.00 & & - & - & - & \\
\hline & Hong Kong & 2.00 & - & 0.50 & & 1.00 & - & & \\
\hline
\end{tabular}




\begin{tabular}{|c|c|c|c|c|c|c|c|c|c|}
\hline \multirow{3}{*}{ Israel } & - & & 0.50 & & - & - & - & \\
\cline { 2 - 9 } & Italy & - & & 0.70 & & - & - & - \\
\cline { 2 - 9 } & Sweden & - & 1.00 & 1.00 & & - & - & - & \\
\hline
\end{tabular}

Figura 2 shows the variation of lead content in the investigated fish species related to the maximum permitted level (MPL) according to above mentioned regulation [37].

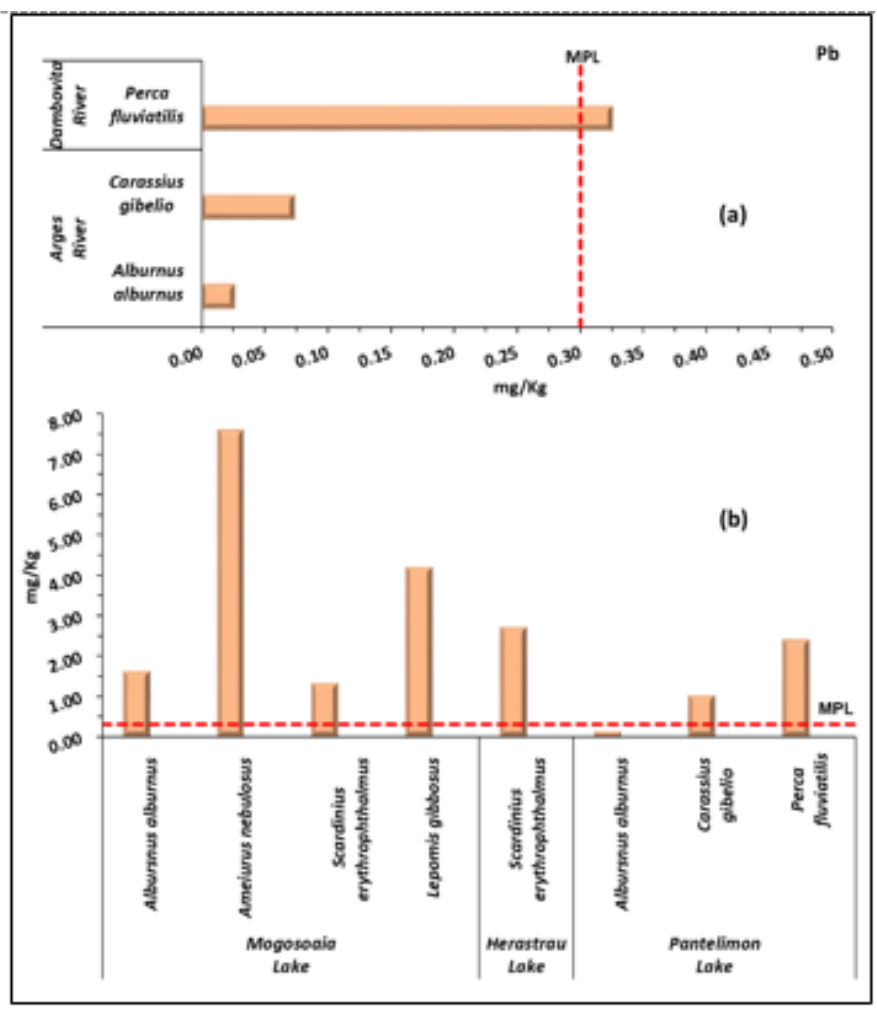

Figure 2. Content of lead in fish muscle tissue: (a) fish samples from the Arges and Dambovita Rivers; (b) fish samples captured from the Mogosoaia, Herastrau and Pantelimon Lakes; MPL - maximum permitted level

As it may be observed in figure 2, the obtained concentration of lead in fish muscle tissue ranged between a minimum value $(0.027 \mathrm{mg} / \mathrm{kg})$ for Alburnus alburnus captured from the Arges River and a maximum value $(7.611 \mathrm{mg} / \mathrm{kg}$ ) for Ameiurus nebulosus captured from the Mogosoaia Lake. The comparative analysis of the results with the maximum allowable levels provided by the legislation $(0.3$ $\mathrm{mg} / \mathrm{kg}$ ) has highlighted the following aspects: (I) the values for $\mathrm{Pb}$ in muscle tissue were smaller than the allowable level in the case of Carassius gibelio (from Arges River), Alburnus alburnus (from Arges River and Pantelimon Lake) and Perca fluviatilis (from Dambovita River); (II) for the other four fish samples captured from the Mogosoaia Lake, the values for $\mathrm{Pb}$ exceeded the maximum permitted level [37], being approximately 25 times larger in the case of Ameiurus nebulosus, 14 times for Lepomis gibbosus, 5 times for Alburnus alburnus and 4 times for Scardinius erythrophthalmus; (III) for Scardinius erythrophthalmus (Herastrau Lake), the analysed $\mathrm{Pb}$ concentration exceeded by approximately 9 times maximum permitted level; (IV) for Carassius gibelio and Perca fluviatilis (Pantelimon Lake), the concentrations exceeded by approximately 3 and respectively 8 times the maximum permitted level.

Figure 3 shows the variation of the cadmium content in fish samples related to the maximum permitted level (MPL) [37]. 


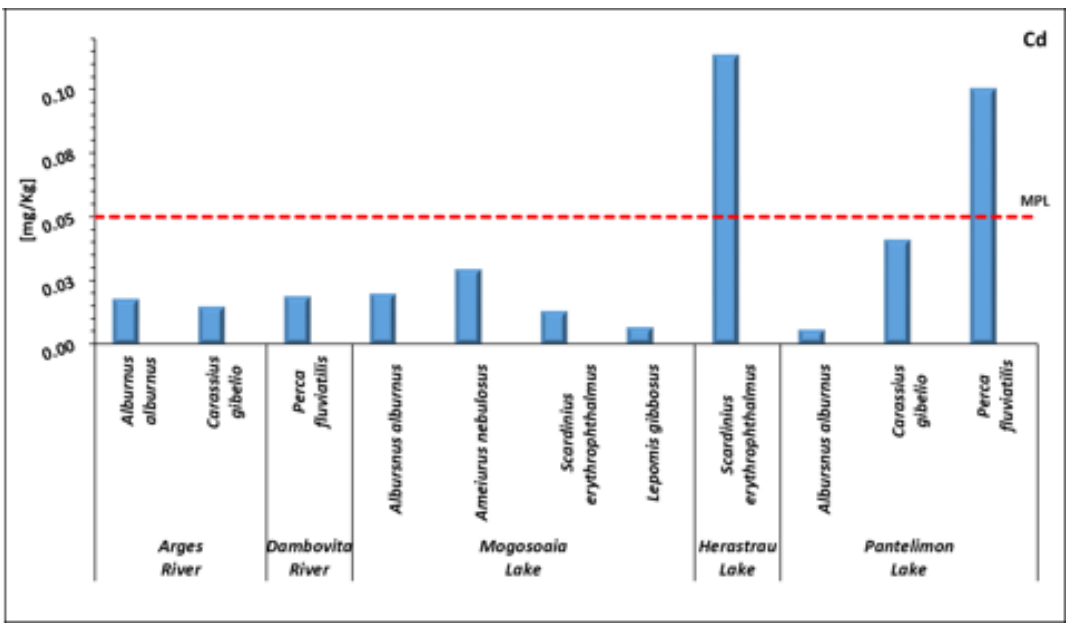

Figure 3. Content of cadmium in the muscle tissue of investigated fish samples; MPL- maximum permitted level

The content of cadmium in fish muscle tissue has shown minimum values $(0.005 \mathrm{mg} / \mathrm{kg})$ for Alburnus alburnus sampled from the Pantelimon Lake and maximum values $(0.113 \mathrm{mg} / \mathrm{kg})$ for Scardinius erythrophthalmus captured from the Mogosoaia Lake. For Scardinius erythrophthalmus captured from the Herastrau Lake and Perca fluviatilis from the Pantelimon Lake, the values of Cd exceeded by approximately two times the maximum permitted level.

According to the data depicted in figure 4, the mercury concentrations in fish muscle tissue were maximum $(1.182 \mathrm{mg} / \mathrm{kg}$ ) for Perca fluviatilis captured in the Dambovita River (Figure 4.a) and minimum $(0.019 \mathrm{mg} / \mathrm{kg})$ for the Carassius gibelio captured from the Pantelimon Lake (Figure 4.b).

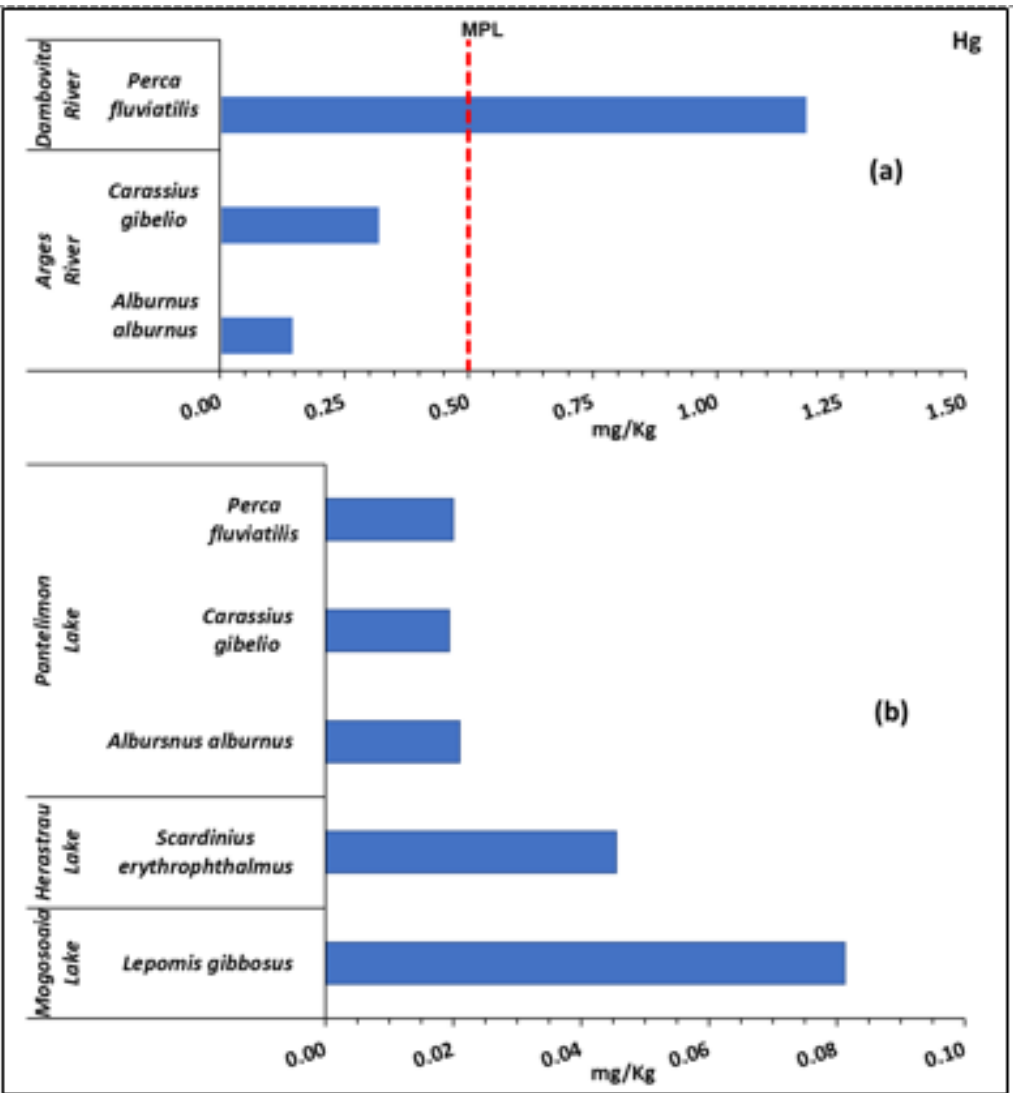

Figure 4. Contend of mercury in fish muscle tissue: (a) fish samples captured from the Arges and Dambovita Rivers;

(b) fish samples captured from the Mogosoaia, Herastrau and Pantelimon Lakes; MPL - maximum permitted level 
The comparative analysis with the maximum permitted level $(0.5 \mathrm{mg} / \mathrm{kg})$ provided by the legislation [37] showed that the level determined in muscle tissue exceeded this level only in the case of Perca fluviatilis (Dambovita River) by approximately 2.5 times.

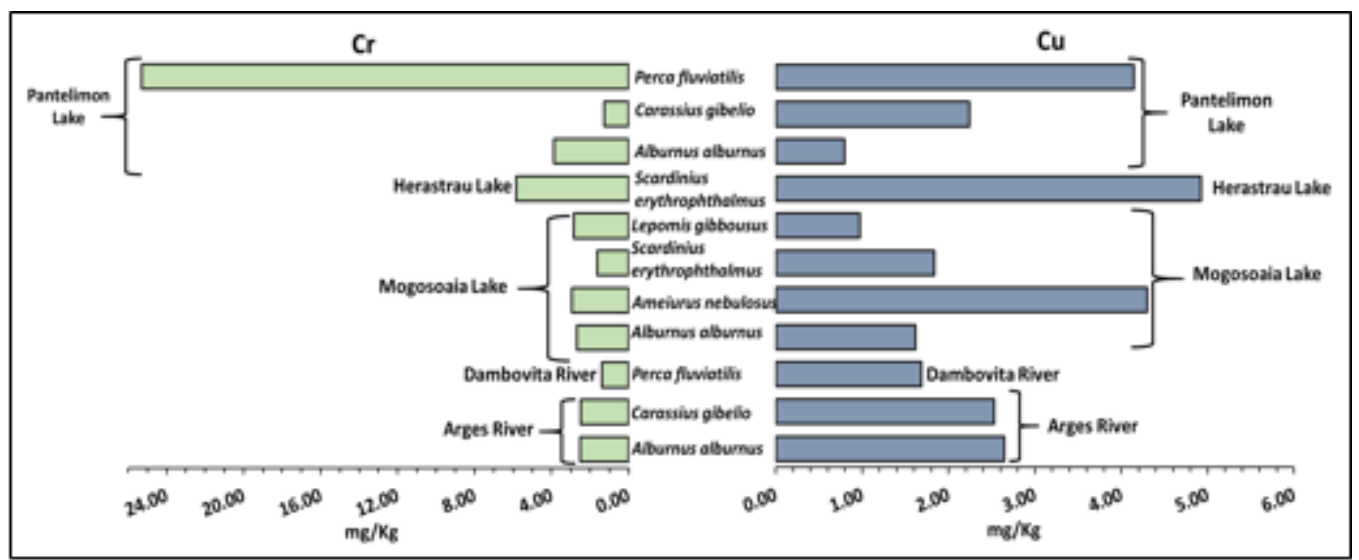

Figure 5. Contend of chromium and copper in muscle tissue from fish samples

As it may be seen in figure 5, the content of chromium was significantly greater in muscle tissue of Perca fluviatilias captured from the Pantelimon Lake, followed by the Scardinius erythrophthalmus captured from the Herastrau Lake in comparaison with other fish species. The content of copper was the highest in muscle tissue from Scardinius erythrophthalmus (from Herastrau Lake), Ameiurus nebulosus (from Mogosoaia Lake) and Perca fluviatilis (from Pantelimon Lake). Generally, the concentration of $\mathrm{Cu}$ was higher than the concentration of $\mathrm{Cr}$ in fish species captured from the Arges River and Dambovita River. For Alburnus alburnus (from Mogosoaia and Pantelimon Lakes) and Perca fluvialtilis (from Pantelimon Lake) the values for $\mathrm{Cr}$ were significantly higher compared to $\mathrm{Cu}$ values. It was found that the $\mathrm{Cu}$ and $\mathrm{Cr}$ concentrations in muscle tissue were below the maximum permitted level [42].

Figure 6 shows the comparative analysis of $\mathrm{Ni}$ and $\mathrm{Zn}$ in muscle tissue for the investigated species.

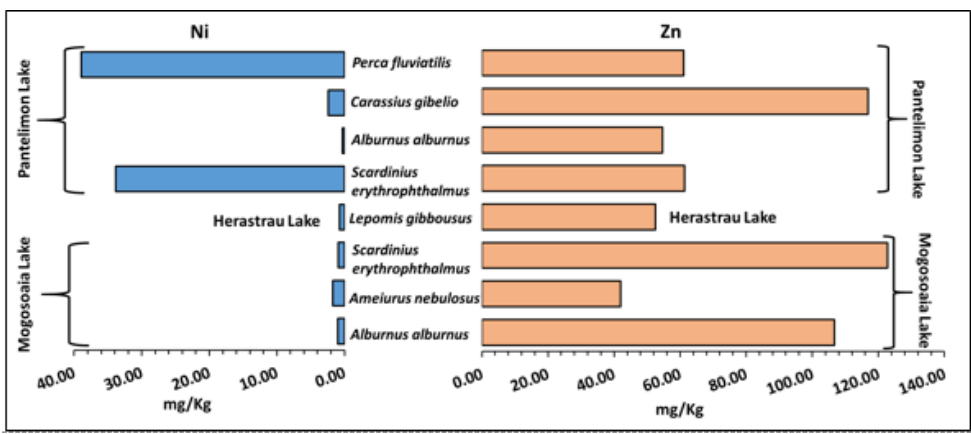

Figure 6. Contend of nickel and zinc in muscle tissue from fish samples

Generally, the values for $\mathrm{Zn}$ showed significantly higher differences compared to Ni values. The $\mathrm{Ni}$ content was significantly higher in the muscle tissue from Perca fluviatilias (from Pantelimon Lake) and Scardinius erythrophthalmus (from Herastrau Lake). As regards the other fish species, no significant differences were found. The maximum values of $\mathrm{Zn}$ were determined for the muscle tissue of Scardinius erythrophthalmus and Alburnus alburnus captured from the Mogosoaia Lake and Carassius gibelio captured from the Pantelimon Lake, with no significant differences recorded for the Zn content in the other investigated fish samples. It has been observed that the Ni content in muscle tissue was below the maximum permitted level [42], whereas the Zn content exceeded this level in the case of Scardinius erythrophthalmus and Alburnus alburnus (from Mogosoaia Lake) and Carassius gibelio (from Pantelimon Lake). 
The potentially toxic elements from the muscle tissue of aquatic species are an indicator of prior exposure at these pollutants, as they tend to accumulate in tissues and organs.

\section{Conclusions}

An assessment of potentially toxic elements in muscle tissues of different fish species from three rivers located in the southern part of Romania was performed. The results obtained in this study provide useful information on the content of potentially toxic elements, especially heavy metals, present in muscle tissue of different fish species captured from Colentina (Mogosoaia, Herastrau and Pantelimon Lakes), Dambovita and Arges Rivers. Thus, although some fish species live in the same conditions, some differences were identified as regards the accumulation of potentially toxic elements in muscle tissues. These differences may be due to their diet, age, position in the trophic chain and contamination gradients.

As regards the concentration of $\mathrm{Cd}$, higher values compared to the maximum permitted level provided by the Commission Regulation 1881/2006 were observed for Scardinius erythrophthalmus (Herastrau Lake) and Perca fluviatilis (Pantelimon Lake). In general, the values of $\mathrm{Pb}$ exceeded the maximum permitted level for all investigated fish species, except for those sampled from the Arges River. Significant variation was observed in the case of $\mathrm{Hg}$ concentrations in the fish species captured from the lakes along the Colentina River and the species captured from the Arges and Dambovita Rivers. In the case of Perca fluviatilis captured from the Dambovita River, the $\mathrm{Hg}$ concentration in muscle tissue was higher that the limit recommended. As regarding the content of $\mathrm{Cr}, \mathrm{Co}$ and $\mathrm{Ni}$, the concentration values did not exceed the maximum permitted level provided by the World Health Organisation (1989). It has been observed that the $\mathrm{Zn}$ content in Scardinius erythrophthalmus and Alburnus alburnus (Mogosoaia Lake) and Carassius gibelio (Pantelimon Lake) showed slightly higher values compared to the maximum permitted level.

In order to prevent the risks associated with the consumption of contaminated fish on human health, frequent monitoring of water, sediments and biota is needed regarding contamination with potentially toxic elements and at the same time educating people about this potential risk.

Acknowledgements. This work used data obtained through the MEVAS 48N/2016 (PN16040104) and MARES 43N/2018 (PN 18260102). The authors would like to thank the management and employees of National Institute for Research and Development in Environmental Protection for their valuable assistance and suggestions. Petra Ionescu's contribution was partially financed by the Operational Programme Human Capital of the Ministry of European Funds through the Financial Agreement 51668/09.07.2019, SMIS code 124705.

\section{References}

1. MCKINLEY, K., MCLELLAN, I., GAGNE, F., QUINN, B., Sci Total Environ, 665, 2019, p. 848.

2. XIA, W., CHEN, L., DENG, X., LIANG, G., GIESY., J. P., RAO, Q., WEN, Z., WU, Y., CHEN, J., XIE, P., Sci Total Environ, 672, 2019, p. 883.

3. IONESCU, P., DEAK, Gy., DIACU, E., RADU, V.-M, Rev. Chim., 67, (11), 2016, 2148.

4. DEAK, Gy., DUMITRU, F.-D, MONCEA, M.-A., PANAIT, A.-M., BOBOC, M., DANALACHE, T, HOLBAN, E., MARINESCU, F., GHEORGHE, P. I, CIOBOTARU, I., ROZAINY, M. R., AIP Conf. Proc. 2129, 2019, p. 020067-1 (https://doi.org/10.1063/1.5118075).

5. JIANG, Z., XU, N., LIU, B., ZHOU, L., WANG, J., WANG, C., DAI, B., XIONG, W., Ecotoxicol. Environ. Saf., 157, 2018, p. 1.

6.ALI, H., KHAN, E., ILAHI, I., Journal of Chemistry, 2019, article ID 6730305, https://doi.org/ $10.1155 / 2019 / 6730305$.

7. *** Directive 2000/60/EC of the European Parliament and of the Council establishing a framework for Community action in the field of water policy. 
8. ***Directive 2008/105/EC of the European Parliament and of the Council of 16 December 2008 on environmental quality standards in the field of water policy, amending and subsequently repealing Council Directives 82/176/EEC, 83/513/EEC, 84/156/EEC, 84/491/EEC, 86/280/EEC and amending Directive 2000/60/EC of the European Parliament and of the Council.

9.***Commission Directive 2009/90/EC Laying Down, Pursuant to Directive 2000/60/EC of the European Parliament and of the Council, Technical Specifications for Chemical Analysis and Monitoring of Water Status.

10.*** Directive 2013/39/EU of the European Parliament and of the Council of 12 August 2013 amending Directives 2000/60/EC and 2008/105/EC as regards priority substances in the field of water policy.

11.***European Communities Technical Report 2009 - 025, Common implementation strategy for the Water Framework directive (2000/60/EC), Guidance Document No. 19 Guidance on Surface Water Chemical Monitoring Under the Water Framework Directive.

12. SOLTANI, N., MOORE, F., KESHAVARZI, B., SOROOSHIAN, A., JAVID, R., Ecotox Environ Safe, 173, 2019, p. 251.

13. SOPHIA, S., MILTON, M. C. J., Sci Total Environ, 12, no. 11, 2017, p. 1831.

14. MILACIC, R., ZULIANI, T., VIDMAR, J., BERGANT, M., KALOGIANNI, E., SMETI, E., SKOULIKIDIS, N., SCANCAR, J., Sci Total Environ, 648, 2019, p. 1087.

15. ZULIANI, T., VIDMAR, J., DRINCIC, A., SCANCAR, J., HORVAT, M., NECEMER, M., PIRIA, M., SIMONOVIC, P., PAUNOVIC, M., MILACIC, R., Sci Total Environ, 650, 2019, p. 958.

16. RADU, V.-M., DIACU, E., IONESCU, P. IVANOV A. A., U.P.B., Sci. Bull. Seria B, 79, 2017 , p. 3.

17. LANE, E. A., CANTY, M. J., MORE S. J, Res. Vet. Sci., 101, 2015, p. 132.

18. WANG, J., ZHU, X., HUANG, X., GU, L., CHEN Y., YANG Z., Scientific Reports, 2016, 6, no. 30968, doi: 10.1038/srep30968.

19. PIAZZA, V., GAMBARDELlA, C., CANEPA, S., COSTA, E., FAIMALI, M., GARAVENTA, F., Ecotox Environ Safe, 123, 2016, p. 8.

20. JAISHANKAR, M., TSETEN, T., ANBALAGAN, N., MATHEW, B. B., Interdiscip Toxicol., 7, no. 2, 2014, p. 60.

21. AFSHAN, S., ALI, S., AMEEN, U. S., FARID, M., BHARWANA, F. A., HANNAN F., AHMAD, R., Res. J. Chem. Env. Sci, 2, no. 1, 2014, p. 74.

22. SVOBODOVA, Z., LLOYD, R., MACHOVA J., VYKUSOVA B., EIFAC Tehnical Paper, FAO, 1993, no. 54.

23. STANCHEVA, M., MAKEDONSKI, L., PEYCHEVA, K., Bulgarian Chemical Communications, 46, no. 1, 2014, pp. 195.

24. SOLOMON, F., Environment and Communities, MINING.com, 2008.

25. CHANDA, S., PAUL, B. N., GHOSH, K., GIRI, S.S., Agri. Review, 36, no. 2, 2015, p.100.

26. WOODY, C.A, O’NEAL, S. L., AK: Fisheries Research and Consulting Anchorage, Alaska 2012.

27. BAKSHI, A., PANIGRAHI, A. K., Toxicology Reports, 5, 2018, p. 440.

28. PAlERMO, F., WAGNER, R. F., SIMONATO, D. J., MARTINEZ, R. B. C., Ecotoxol. Environ. Saf., 116, 2015, p. 19.

29. BLEWETT, T.A., WOOD, C.M., GLOVER, C.N., Environ. Pollut., 214, 2016 p. 132.

30. JAN, A.T, AZAM, M., SIDDIQUI, K., ALI, A., CHOI, I., RIZWANUL HAQ, Q. M., Int. J. Mol. Sci. 16, 2015, p. 29592.

31. ***World Health Organization, Environmental Health Criteria 221: Zinc, Geneva, 2001.

32. DIUDEA, M., TODOR, S., IGNAT, A., Toxicologia acvatică, Editura Dacia, 1986. 
33. IONESCU, P., RADU, V.-M., IVANOV, A. A., DEAK, Gy., DIACU, E., MARCU, E., ANGHEL, A.-M., Quality Assessment of Some Freshwater Resources Located in Bucharest and Surrounding Areas. Part II. Case Study: Water Quality Assessment of Arges and Dambovita Rivers, Rev. Chim., 70, (10), 2019, 3638

34. IONESCU, P., RADU, V.-M., DEAK, Gy., DIACU, E., MARCU, E., CIOBOTARU, I.-E., Quality Assessment of Some Freshwater Resources Located in Bucharest and Surrounding Areas. Part I. Case Study: Water Quality Assessment of Herastrau, Pantelimon and Mogosoaia Lakes, Rev. Chim., 70, (8), 2019, p. 2889.

35. ZAMFIR, A.-S. DEAK, Gy., DANALACHE, T. M., GEORGESCU, P. L., RAISCHI, M.C., CRISTEA, A., OPREA, L., LUMINAROIU, L. G., AIP Conference Proceedings, 2129, 2019, p. 020075-1.

36.***COMMISSION REGULATION (EC) No 466/2001 setting maximum levels for certain contaminants in foodstuffs.

37.*** COMMISSION REGULATION (EC), No 1881/2006 setting maximum levels for certain contaminants in foodstuffs.

38.***COMMISSION REGULATION (EC), No 629/2008 amending regulation (EC) no. 1881/2006 setting maximum levels for certain contaminants in foodstuffs.

39.***COMMISSION REGULATION (EC) No 78/2005 amending Regulation (EC) No 466/2001 as regards heavy metals Text with EEA relevance.

40.***Australia New Zealand Food Standards Code - Standard 1.4.1 - Contaminants and Natural Toxicants https://www.legislation. gov.au/ Details/F2011C00542

41. CODEX STAN 193-1995 General Standard for Contaminants and Toxins in Food and Feed, 2018.

42. MOKHTAR, M. B., European Journal of Scientific Research, 30, no.3, 2009, p. 348.

43. NAUEN, C.E., Compilation of legal limits for hazardous substances in fish and fishery products, FAO Fisher Circular, no. 764, 1983, Rome.

Manuscript received: 25.10.2019 